\title{
INTERNALISASI NILAI-NILAI UKHUWAH ISLAMIYAH MELALUI KEGIATAN RUKUN KEMATIAN NURUD DHOLAM DI DESA GLUNDENGAN WULUHAN KABUPATEN JEMBER
}

\author{
Ika Nafisatus Zuhro \\ Prodi PAI FTIK IAIN Jember \\ Ikanafisa1998@gmail.com \\ Imron Fauzi \\ Prodi PAI FTIK IAIN Jember \\ imronfauzi@iain-jember.ac.id
}

\begin{abstract}
Abstrak
Ukhuwah Islamiyah merupakan hubungan sesama muslim tanpa membedakan luas dan sempitnya kapasitas hubungan, mulai dari hubungan keluarga, masyarakat sampai hubungan antar bangsa. Hal ini terbukti dengan masih banyak masyarakat yang belum mengerti atau kurangnya memahami sifat sosial seperti tolong menolong, khususnya dalam hal yang berkaitan dengan kematian, da ada beberapa masyarakat yang ditinggalkan kurang mampu, sehingga belum terlaksananya dengan baik kegiatan mengurus jenazah. Penelitian ini dilakukan: (1) untuk mendeskripsikan internalisasi nilai-nilai ukhuwah Islamiyah melalui kegiatan Rukun Kematian Nurud Dholam di Desa Glundengan Wuluhan, (2) untuk mendeskripsikan bentuk-bentuk kegiatan Rukun Kematian Nurud Dholam di Desa Glundengan Wuluhan, dan (3) untuk mendeskripsikan faktor pendukung dan penghambat kegiatan Rukun Kematian Nurud Dholam di Desa Glundengan Wuluhan. Metode penelitian ini menggunakan penelitian kualitatif, dengan menggunakan teknik pengambilan data sampel purposive. Jenis Pendekatan menggunakan Deskriptif. Analisis data model Miles Huberman yang meliputi: pengumpulan data, kondensasi data, penyajian data, dan penarikan simpulan. Sedangkan pengecekan keabsahan data menggunakan triangulasi sumber dan teknik. Hasil penelitian ini: (1) internalisasi nilai-nilai ukhuwah Islamiyah melalui kegiatan Rukun Kematian Nurud Dholam yaitu sudah berjalan dengan baik akan tetapi kurangnya kesadaran masyarakat dalam hal keagamaan. (2) Bentuk- bentuk kegiatan Rukun Kematian Nurud Dholam adalah mengurus jenazah, membersihkan area makam, sosialisasi, penggalian dana, dan pemeliharaan aset Rukun Kematian yaitu berbentuk pohon sengon. (3) Faktor pendukung kegiatan Rukun Kematian Nurud Dholam adalah adanya dorongan baik dari pemerintah desa maupun masyarakat, untuk saling bergotong royong. Sedangkan factor penghambat kegiatan RUKEM Nurud Dholam adalah kurangnya kesadaran masyarakat, dan sangat minimnya pemberdayaan masyarakat.
\end{abstract}

Kata kunci: nilai-nilai ukhuwah Islamiyah, rukun kematian

\begin{abstract}
Ukhuwah Islamiyah is a relationship between Muslims without distinguishing the breadth and narrowness of the capacity of relations, ranging from family relations,
\end{abstract}




\section{AL-ADABIYAH: Jurnal Pendidikan Agama Islam}

community relations between nations. This is proven by the fact that there are still many people who do not understand or lack understanding of social characteristics such as helping, especially in matters relating to death, and there are some people who are left disadvantaged, so that they have not properly carried out the care of the corpse. From this research was carried out to describe the internalization of the values of Ukhuwah Islamiyah through the activities of the Pillars of Death Nurud Dholam in Glundengan Wuluhan Village, to describe the forms of the activities of the Pillars of Death of Nurud Dholam in Glundengan Wuluhan Village, to describe the supporting factors and the activities of the Pillars of Death Nurud Dholam inhibiting the activities of the Pillars of Death (Rukem) Nurud Dholam in Glundengan Wuluhan Village. This research method uses qualitative research, using purposive sample data collection techniques. This type of approach uses descriptive. Analysis of Miles Huberman model data which includes: data collection, data condensation, data presentation, and drawing conclusions. While checking the validity of the data using triangulation (sources and techniques). So that this study concluded: (1) internalisation of ukhuwah Islamiyah values through the Pillars of Death Nurud Dholam that is already going well but the lack of public awareness in religious matters. (2) The forms of the Rukun Death activity of Nurud Dholam are taking care of the body, cleaning up the grave area, socializing, raising funds, and maintaining Pillars of Death assets, namely in the form of sengon trees. 3) Supporting factors for the activities of Pillars of Death Nurud Dholam are the encouragement from both the village government and the community to work together. Whereas the inhibiting factor of Pillars of Death Nurud Dholam's activities was the lack of public awareness, and the very lack of community empowerment.

Keywords: ukhuwah Islamiyah values, pillars of death

\section{Pendahuluan}

Manusia beriman mempunyai dua dimensi hubungan yang harus selalu dipelihara dan dilaksanakan, yakni hubungan vertikal dengan Allah Swt melalui shalat dan ibadah-ibadah lainnya, dan hubungan horizontal dengan sesama manusia di masyarakat dalam bentuk perbuatan baik. Mukmin niscaya menjaga harmoni, keseimbangan, equilibrium antara intensitas hubungan vertikal dan hubungan horizontal.

Orientasi hubungan vertikal disimbolkan oleh pencarian keselamatan dan kebaikan hidup di akhirat, sedangkan hubungan horizontal diorientasikan pada perolehan kebaikan dan keselamatan hidup di dunia. Dalam situasi dan kondisi tertentu, kesetiakawanan sosial itu diwujudkan dalam bentuk kesanggupan membela mereka yang tertindas.

Interaksi manusia dengan sesamanya harus didasari keyakinan bahwa semua manusia adalah bersaudara, dan bahwa anggota masyarakat Muslim juga saling bersaudara. Ukhuwah mengandung arti persamaan dan keserasian dalam banyak hal. Karenanya persamaan dalam keturunan mengakibatkan 


\section{AL-ADABIYAH: Jurnal Pendidikan Agama Islam}

persaudaraan, dan persamaan dalam sifat-sifat juga membuahkan persaudaraan. Jalinan ukhuwah di antara manusia seperti ukhuwah Islamiyah. Ukhuwah Islamiyah merupakan hubungan sesama umat manusia tanpa membedakan luas dan sempitnya kapasitas hubungan, mulai hubungan keluarga, masyarakat kcil sampai hubungan antara bangsa. Hubungan ini mempunyai bobot religius disamping makna dan bobot yang lain. Hal ini penting, karena dalam jiwa manusia terdapat sisi-sisi religius, di mana setiap seseorang di dalam kesehariannya selalu membutuhkan rasa tenang dan kedamaian dalam hidup bermasyarakat.

Sebagaimana dijelaskan dalam al-Quran surat al-Hujurat ayat 10: "Orangorang beriman itu sesungguhnya bersaudara.Sebab itu damaikanlah (perbaikilah hubungan) antara kedua saudaramu itu dan takutlah terhadap Allah, supaya kamu mendapat rahmat."

Ayat di atas menegaskan bahwa manusia menurut fitrahnya adalah umat yang terpadu dan bersatu, suka bekerja sama, bahu membahu, saling membantu dan saling menjaga aib satu dengan aib yang lainnya. Oleh karena itu, Allah memerintahkan kaum muslimin dengan memupuk persatuan, agar tidak mudah dipecah-belah dan tidak mengumbar aib satu sama lain serta mengatur hubungan satu sama lain melalui tolong menolong dan saling bantu membantu.

Berdasarkan hasil observasi awal peneliti yang dilakukan di desa Gundengan kecamatan Wuluhan peneliti menemukan bahwa masih banyak masyarakat yang belum mengerti atau kurangnya memahami sifat sosial seperti tolong menolong, khususnya dalam hal yang berkaitan dengan kematian, sehingga belum terlaksananya dengan baik kegiatan mengurus jenazah yaitu memandikan jenazah, mengkafani jenazah, menshalati jenazah dan mengkubur jenazah. Dan ada bebarapa masyarakat yang ditinggalkan kurang mampu dalam hal biaya sehingga membutuhkan bantuan dana untuk merawat jenazah. Dengan rendahnya pemahaman dan kemampuan finansial masyarakat di desa Glundengan sehingga membutuhkan wadah untuk menanggulangi masalah tersebut, khususnya organisasi Rukun Kematian Nurud Dholam yang ada di desa Glundengan.

Rukun kematian Nurud Dholam adalah suatu wadah kegiatan sosial yang dimiliki warga masyarakat desa Glundengan Wuluhan yang memberikan pelayanan jasa kematian seperti mengurus jenazah, menyediakan kebutuhan perlengkapan jenazah, menyiapkan peralatan tahlilan, program bulanan seperti penggalian dana dan rapat anggota RUKEM. Dan program tahunan seperti sosialisasi. Serta 


\section{AL-ADABIYAH: Jurnal Pendidikan Agama Islam}

terdapat kegiatan penanaman 700 pohon sengon di areal makam dan tanah kongsen yang dimana nanti hasil atau labanya akan digunaka untuk keperluan kegiatan Rukun Kematian Nurud Dholam dan membantu masyarakat yang membutuhkan dalam pengurusan jenazah. Dan anggota RUKEM jika ingin bergabung tidak dipungut biaya dan tidak perlu mendaftarkan dirinya terlebih dahulu karena kegiatan rukun kematian Nurud Dholam ini merupakan swadaya masyarakat desa Glundengan jadi siapapun boleh menjadi anggota Rukun Kematian Nurud Dholam.

Rukun kematian merupakan salah satu bentuk satuan pendidikan non formal yang termasuk dalam jenis Pusat kegiatan belajar masyarakat merupakan satuan pendidikan nonformal yang menyelenggarakan berbagai kegiatan belajar sesuai dengan kebutuhan masyarakat atas dasar prakarsa dari, oleh dan untuk masyarakat. Yang bertujuan untuk meningkatkan pengetahuan, keterampilan, sikap, hobi dan bakat anggota masyarakat sehingga bermanfaat bagi masyarakat dan lingkungannya dalam menjalin sebuah ukhuwah Islamiyah.

Rukun Kematian sebagai salah satu wadah yang berfungsi untuk memberikan pembelajaran mengenai pengurusan jenazah yang terorganisir dengan berpedoman terhadap syariat Islam yaitu al-Quran dan as-Sunnah. Hal tersebut juga dijelaskan dalam UU No. 20 Tahun 2003 tentang Sistem Pendidikan Nasional pasal 26 yang berbunyi bahwa "Masyarakat yang memerlukan layanan pendidikan pengganti pendidikan formal maka diselenggarakan pendidikan non formal untuk mendukung pendidikan sepanjang hayat. Salah satu pendidikan non formal yaitu pusat kegiatan belajar masyarakat."

Pasal 26 tersebut dijabarkan melalui Peraturan Pemerintah No. 17 Tahun 2010 tentang Pengelolaan dan Penyelenggaraan Pendidikan khususnya pasal 105 menyatakan bahwa:

“Tujuan diselenggarakannya pendidikan bagi masyarakat pada pusat kegiatan belajar masyarakat yaitu memperoleh pengetahuan dan keterampilan, keterampilan kecakapan hidup, mengembangkan sikap dan kepribadian professional, mempersiapkan diri untuk berusaha mandiri dan melanjutkan ketingkat yang lebih tinggi. Salah satu pendidikan nonformal yang diperlukan masyarakat."

Pasal 105 tersebut dijelaskan pula melalui Permendikbud No. 81 Tahun 2013 tentang Pendirian Satuan Pendidikan NonFormal menyatakan bahwa:

"Pendidikan nonformal (PNF) adalah jalur pendidikan yang dilaksanakan secara terstruktur dan berjenjang.Pusat kegiatan belajar masyarakat (PKBM) 


\section{AL-ADABIYAH: Jurnal Pendidikan Agama Islam}

merupakan satuan pendidikan nonformal yang menyelenggarakan kegiatan belajar sesuai dengan kebutuhan masyarakat, berdasarkan prakarsa dari, oleh, dan untuk masyarakat."

Nilai-nilai tersebut tersirat dalam kegiatan rukun kematian, karena dalam kegiatan rukun kematian akan terlaksana dengan baik apabila masyarakat memiliki rasa kepedulian yang tinggi terhadap sesama manusia, saling tolong menolong dan menghargai kepada sesama sehingga, terjalinlah hubungan ukhuwah Islamiyah dengan baik.

Kegiatan rukun kematian secara pendidikan kifayah diharapkan masyarakat di desa Glundengan dapat bersama-sama menumbuh kembangkan ukhuwah islamiyah terhadap rukun kematian terutama dalam hal pengurusan jenazah. Sedangkan secara pendidikan insaniyah diharapkan ukhuwah islamiyah muncul atas kesadaran individual seseorang sehingga mereka saling menghargai dan tolong menolong antara satu sama lainnya.

Berangkat dari permasalahan di atas, maka menjadi sebuah keharusan bagi setiap individu untuk kembali mengokohkan nilai-nilai ukhuwah antar umat manusia, terlebih pada sesama umat muslim dengan membangun kembali tali ukhuwah Islamiyah. Hal ini penting, karena setiap muslim menurut ajaran Islam sebenarnya saudara yang mempunyai Iman yang sama. Selain persamaan Iman, tentunya dalam kehidupan bermasyarakat setiap muslim ingin hidup dengan damai, aman, tentram dan penuh kebahagiaan. Kondisi seperti ini tentunya juga dicita-citakan Islam. Dimana agama Islam menghendaki agar manusia bersatu dalam asas kebersamaan persaudaraan, keadilan, kebenaran, saling tolong menolong, saling menasehati dan sebagainya. Tujuan dari penelitian ini adalah sebagai berikut: (1) untuk mendeskripsikan internalisasi nilai-nilai Ukhuwah Islamiyah melalui kegiatan Rukun Kematian (RUKEM) Nurud Dholam di Desa Glundengan Wuluhan, (2) untuk mendeskripsikan bentuk-bentuk kegiatan Rukun Kematian (RUKEM) Nurud Dholam di Desa Glundengan Wuluhan, dan (3) untuk mendeskripsikan faktor pendukung dan penghambat kegiatan Rukun Kematian (RUKEM) Nurud Dholam di Desa Glundengan Wuluhan.

\section{Tinjauan Literatur}

\section{Internalisasi Nilai-Nilai Ukhuwah Islamiyah}

a. Internalisasi 


\section{AL-ADABIYAH: Jurnal Pendidikan Agama Islam}

Secara etimologis, internalisasi menunjukkan suatu proses. Dalam kaidah bahasa Indonesia akhiran -isasi mempunyai definisi proses. Sehingga internalisasi dapat didefinisikan sebagai suatu proses. Dalam kamus besar bahasa Indonesia internalisasi diartikan sebagai penghayatan, pendalaman, penguasaan secara mendalam yang berlangsung melalui binaan, bimbingan dan sabagainya. ${ }^{1}$

Adapun internalisasi secara terminologi adalah proses menjadikan nilai sebagai bagian dari diri seseorang. Lebih lanjut dijelaskan bahwa proses tersebut tercipta dari pendidikan nilai dalam pengertian yang sesungguhnya yaitu terciptanya suasana, lingkungan dan interaksi belajar mengajar yang memungkinkan terjadinya proses sosialisasi dan internalisasi nilai-nilai. Menurut Chabib Thoha internalisasi nilai merupakan teknik dalam pendidikan nilai yang sasarannya adalah sampai pada pemilikan nilai yang menyatu dalam kepribadian peserta didik. ${ }^{2}$

Dalam proses internalisasi ada tiga tahap yang mewakili proses atau tahap terjadinya internalisasi yaitu tahap transformasi nilai, tahap transaksi nilai dan tahap transinternalisasi. ${ }^{3}$

1) Tahap Transformasi Nilai merupakan suatu proses yang dilakukan oleh pendidik dalam menginformasikan nilai-nilai yang baik dan kurang baik. Pada tahap ini hanya terjadi komunikasi verbal antara pendidik dan peserta didik atau anak asuh.

2) Tahap Transaksi Nilai merupakan suatu tahap pendidikan nilai dengan jalan melakukan komunikasi dua arah, atau interaksi antara peserta didik dengan pendidik yang bersifat interaksi timbal-balik.

3) Tahap Transinternalisasi merupakan suatu tahap yang jauh lebih mendalam dari tahap transaksi. Pada tahap ini bukan hanya dilakukan dengan komunikasi verbal tapi juga sikap mental dan kepribadian. Jadi pada tahap ini komunikasi kepribadian yang berperan secara aktif.

b. Nilai-Nilai

Nilai dalam bahasa Inggris adalah "value", dalam bahasa latin disebut "velere", atau bahasa Prancis Kuno "valoir". Nilai dapat diartikan berguna,

${ }^{1}$ Depdikbud, Kamus Besar Bahasa Indonesia, (Jakarta: Balai Pustaka, 1989), 336.

2 Chabib Thoha, Kapita Selekta Pendidikan Islam, (Yogyakarta: Pustaka Pelajar, 2006), 87-93.

${ }^{3}$ Muhamimin, Strategi Belajar Mengajar, (Surabaya: Citra Meida, 2006), 153. 


\section{AL-ADABIYAH: Jurnal Pendidikan Agama Islam}

mampu akan, berdaya, berlaku, bermanfaat dan paling benar menurut keyakinan seseorang atau sekelompok orang. ${ }^{4}$ Nilai mempunyai peranan yang begitu penting dan banyak di dalam hidup manusia, sebab nilai dapat menjadi pegangan hidup, pedoman penyelesaian konflik, memotivasi dan mengarahkan pandangan hidup. Nilai adalah suatu tipe kepercayaan yang berada dalam ruang lingkup sistem kepercayaan, dimana seseorang harus bertindak atau menghindari suatu tindakan mengenai sesuatu yang pantas atau tidak pantas untuk dikerjakan. ${ }^{5}$

Nilai dilihat dari berbagai sudut pandang yang menyebabkan terdapat bermacam-macam nilai, antara lain:

1) Dilihat dari segi kebutuhan hidup manusia, nilai menurut Abraham Maslow dapat dikelompokkan menjadi : "nilai biologis, nilai keamanan, nilai cinta kasih, nilai harga diri dan nilai jati diri.”

2) Dilihat dari kemampuan jiwa manusia untuk menangkap dan mengembangkan nilai dapat dibedakan menjadi dua yakni:

a) Nilai yang statik, seperti kognisi, emosi, dan psikomotor.

b) Nilai yang bersifat dinamis seperti motivasi berprestasi, motivasi berafiliasi, motivasi berkuasa.

3) Nilai bila dilihat dari sumbernya terdapat nilai Ilahiyah (ubudiyah dan muamalah), dan nilai insaniyah. Nilai Ilahiyah adalah nilai yang bersumber dari agama (wahyu Allah Swt), sedangkan nilai insaniyah nilai yang diciptakan oleh manusia atas dasar kriteria yang diciptakan oleh manusia atas dasar kriteria yang diciptakan oleh manusia pula. 6

c. Ukhuwah Islamiyah

1) Pengertian Ukhuwah Islamiyah

Secara Etimologi, Ukhuwah (ukhuwwah) yang biasa diartikan sebagai persaudaraan, berasal dari akar kata yang pada mulanya berarti memperhatikan. Makna asal kata ini memberi kesan bahwa persaudaraan mengharuskan adanya perhatian semua pihak yang bersaudara.

4 Sutarjo Adisusilo, JR. Pembelajaran Nilai Karakter, (Jakarta: PT Rajagrafindo Persada, 2012), 56.

${ }^{5}$ M. Chabib Thoha, Kapita Selekta..., 60.

${ }^{6}$ Thoha, Kapita Selekta..., 63-64. 
Terkait hal tersebut, Quraish Shihab juga menyatakan perhatian itu pada mulanya lahir karena adanya persamaan di antara pihak-pihak yang bersaudara, sehingga makna tersebut kemudian berkembang dan pada akhirnya ukhuwah diartikan sebagai setiap persamaan dan keserasian dengan pihak lain, baik persamaan keturunan, dari segi ibu bapak, atau keduanya maupun dari segi persusuan secara majazi kata ukhuwah (persaudaraan) mencakup persamaan salah satu unsur seperti suku, agama, profesi dan perasaan. ${ }^{7}$

Adapun Secara terminologi Ukhuwah Islamiyah menurut Quraish Shihab, perlu didudukkan maknanya, agar bahasan tentang ukhuwah tidak mengalami kerancuan. Untuk itu terlebih dahulu perlu dilakukan tinjauan kebahasaan untuk menetapkan kedudukan kata Islamiah dalam istilah di atas. Selama ini ada kesan bahwa istilah tersebut bermakna persaudaraan yang dijalin oleh sesama muslim, sehingga dengan demikian kata lain "Islamiah" dijadikan pelaku ukhuwah itu. Pemahaman ini kurang tepat, kata Islamiyah yang dirangkaikan dengan kata ukhuwah lebih tepat dipahami sebagai ajektifa, sehingga Ukhuwah Islamiyah berarti persaudaraan yang bersifat Islami atau yang diajarkan oleh Islam. ${ }^{8}$

Menurut Tholhah Hasan, Ukhuwah Islamiyah merupakan hubungan sesama muslim tanpa membedakan luas dan sempitnya kapasitas hubungan, mulai dari hubungan keluarga, masyarakat sampai hubungan antar bangsa, hubungan ini mempunyai bobot religious. 9

2) Tujuan Ukhuwah Islamiyah

Ukhuwah atau persaudaraan dapat berdasarkan pertalian darah dan keturunan (biologis, karena hubungan perkawinan, ikatan keluarga, budaya adat dan lain-lain). Berbeda dengan persaudaraan Islam, tali yang menghubungkannya yakni akidah, persamaan kepercayaan yang diperkuat pula oleh ruh dan semangat ketaatan yang sama kepada pencipta alam semesta ini. Adapun salah satu ukhuwah seorang muslim yakni cintanya kepada sesama saudara seiman. Ikatan yang menghubungkan seorang muslim dengan saudaranya, tanpa

${ }^{7}$ Shihab, Wawasan Alquran, 486.

8 Shihab, Wawasan Alquran, 486-487.

${ }^{9}$ Hasan, Prospek Islam Dalam Menghadapi Tatanan Zaman, 24. 
memandang ras, warna kulit atau bahasa merupakan ikatan iman kepada Allah. Persaudaraan karena iman merupakan ikatan yang kuat antara hati dan pikiran. Tidak mengherankan perasaan persaudaraan ini akan melahirkan perasaan-perasaan mulia dalam jiwa seorang muslim dan membentuk sikap positif serta menjauhkan sikap-sikap negatif.

3) Macam-Macam Nilai-Nilai Ukhuwah Islamiyah

Nilai-nilai Ukhuwah Islamiyah menurut Quraish Shihab setidaknya ada empat macam, diantaranya yaitu:

a) Ukhuwah Ubudiyah

Ukhuwah Ubudiyah adalah saudara sesama makhluk dan kesetundukan kepada Allah.Pengertian tersebut menjelaskan bahwa seluruh makhluk hidup adalah bersaudara dalam arti memiliki persamaan dan sama-sama ciptaan Allah SWT.

b) Ukhuwah Insaniyah

Ukhuwah Insaniyah adalah saudara sesama manusia. Dalam artian, seluruh manusia baik itu beda agama, suku dan ras adalah bersaudara. Mereka semua bersumber dari satu ayah dan ibu yaitu Adam dan Hawa. Hal ini berarti bahwa manusia itu diciptakan dari seorang laki-laki dan seorang perempuan.

c) Ukhuwah Wathaniyah wa Nasab

Ukhuwah Wathaniyah wa Nasab yaitu persaudaraan dalam kebangsaan dan keturunan. Ayat-ayat macam ini banyak dan hampir mendominasi semua ukhuwah.

d) Ukhuwah fi Din al Islam

Ukhuwah fi Din al Islam adalah persaudaraan antar sesama muslim. Dengan arti lain, menurut ajaran Islam bahwa antar sesama muslim itu adalah saudara.

Konsep Ukhuwah yang dikembangkan KH. Ahmad Siddiq disebut trilogi Ukhuwah adalah sebagai berikut:

a) Ukhuwah Islamiyah yaitu ukhuwah yang tumbuh dan berkembang karena persamaan keamanan atau keagamaan, baik ditingkat Nasional maupun Internasional. Sebagai modal untuk melakukan pergaulan sosial dengan sesama muslim. 
b) Ukhuwah Wathaniyah yaitu ukhuwah yang tumbuh dan berkembang atas dasar kebangsaan. Sebagai modal untuk melakukan pergaulan social dan dialog dengan berbagai komponen bangsa Indonesia.

c) Ukhuwah Basyariyah yaitu ukhuwah yang tumbuh dan berkembang atas dasar kemanusiaan. Agar terwujudnya Ukhuwah Basyariyah kedua ukhuwah (Islamiyah dan Wathaniyah) harus dijalankan bersama-sama dan serentak karena kedunya saling mendukung dan saling membutuhkan, tidak boleh dipertentangkan satu dengan yang lain. ${ }^{10}$

Dengan mengacu pada empat pedoman ukhuwah Islamiyah yaitu Ukhuwah Ubudiyah, Ukhuwah Insaniyah, Ukhuwah Wathaniyah Wa Nasab dan Ukhuwah Fi Din al Islam, sama halnya dengan mengacu konsep yang dikembangkan KH. Ahmad Siddiq sebagai berikut Ukhuwah Islamiyah yang terdiri dari Ukhuwah Ubudiyah dan Fi Din al Islam, Ukhuwah Wathaniyah (Ukhuwah Wathaniyah wa Nasab), dan Ukhuwah Basyariyah (Ukhuwah Insaniyah). Maka peneliti dapat menyimpulkan bahwa makna dari ukhuwah Islamiyah adalah persaudaraan yang tumbuh dan berkembang karena persamaan keamanan atau keagamaan. Dan setidaknya mereka menyadari dan memahami pentingnya makna tentang persaudaraan antar umat muslim, sehingga akan timbul suatu kerja sama dan gotong royong agar terciptalah suatu masyarakat antar peradaban yang serasi dan harmonis. Akhirnya terbentuklah suatu masyarakat yang ideal, yaitu sosok masyarakat yang diwarnai oleh jalinan solidaritas sosial yang tinggi, rasa persaudaraan yang solid antar sesama muslim khususnya dalam membantu mengurus sesama muslim yang sudah meninggal.

4) Manfaat Ukhuwah Islamiyah

Manfaat dalam sebuah persaudaraan adalah sebagai berikut:

a) Kelezatan iman yang akan mewujudkan kehidupan bahagia.

b) Limpahan rahmat Allah dan dijaga dari malapetaka hari kiamat.

10 Rudy Al Hana, "Pemikiran KH. Achmad Siddiq Tentang Ukhuwah Islamiyah, Wathaniyah, Basyariyah", dalam Study Islam, vol IV, Agustus, 2004), 2. 
c) Keamanan dan kegembiraan serta termasuk dalam tujuh golongan yang beruntung mendapat naungan Allah pada hari yang tiada naungan selain naungan-Nya.

d) Persaudaraan dapat memasuki surga yang paling tinggi derajatnya.

e) Persaudaraan akan merasakan ketentraman, kesentosaan, aman dari prahara, dan pada hari kiamat kelak wajahnya mencorong berseri-seri.

f) Persaudaraan kan terjaminnya keselamatan.

g) Persaudaraan karena Allah merupakan amal shaleh yang dapat mengundang datangnya hidayah dan keberuntungan.

h) Orang yang mengajak kepada mahabah dan ukhuwah akan diganjar pahala besar.

i) Persaudaraan merupakan bukti ketaatan kepada Allah.

j) Persaudaraan merupakan tanggung jawab sosial dan kemanusiaan. ${ }^{11}$

5) Faktor yang mempengaruhi internalisasi nilai-nilai Ukhuwah Islamiyah

Adapun Faktor yang mempengaruhi internalisasi nilai-nilai Ukhuwah Islamiyah adalah sebagai berikut:

a) Faktor Pendukung Nilai-Nilai Ukhuwah Islamiyah

(1) Faktor Internal yang meliputi motivasi dan empati.

(2) Faktor Eksternal yang meliputi budaya lingkungan, menciptakan perdamaian dan tingkat pendidikan.

b) Faktor Penghambat Nilai-Nilai Ukhuwah Islamiyah

(1) Faktor Internal yang meliputi keras kepala dan tidak mau mendengarkan nasihat atau usulan pada saat rapat, ingkar janji tanpa udzur.

(2) Faktor Eksternal yang meliputi berhati dingin dan mudah terhasut.

\section{Kegiatan Rukun Kematian}

a. Konsep Kegiatan Rukun Kematian

${ }^{11}$ Abdullah bin Jarullah bin Ibrahim, Ukhuwah Islamiyah, (Yogyakarta: Insan Madani, 2008), 24. 
Rukun kematian merupakan salah satu bentuk satuan pendidikan non formal yang termasuk dalam jenis pusat kegiatan belajar masyarakat, yang merupakan satuan pendidikan nonformal yang menyelenggarakan berbagai kegiatan belajar sesuai dengan kebutuhan masyarakat atas dasar prakarsa dari, oleh dan untuk masyarakat. Rukun kematian bertujuan untuk meningkatkan pengetahuan, keterampilan, sikap, hobi dan bakat anggota masyarakat sehingga bermanfaat bagi masyarakat dan lingkungannya dalam menjalin sebuah ukhuwah Islamiyah.

Secara etimologi rukun kematian berasal dari dua kata yaitu rukun dan kematian. Adapun rukun menurut Kurniawan menyatakan bahwa rukun merupakan sesuatu pekerjaan yang harus dimulai sebelum melakukan pekerjaan. ${ }^{12}$ Menurut Imam Ghazali mengartikan bahwa kematian adalah ungkapan tak berfungsinya semua anggota tubuh yang memang merupakan alat-alat ruh. ${ }^{13}$

Secara terminologi rukun kematian merupakan suatu kegiatan yang bertujuan untuk membantu warga masyarakat yang mengalami musibah dengan bergotong royong dalam membantu apa saja yang dibutuhkan bagi keluarga yang membutuhkan. ${ }^{14}$

b. Bentuk-bentuk Kegiatan Rukun Kematian

1) Pengurusan Jenazah

Pokok pengurusan jenazah terdapat lima tahap yaitu memandikan jenazah, mengkafani jenazah, menyalatkan jenazah dan mengkuburkan jenazah. Kecuali bagi jenazah yang mati syahid, cukup dishalatkan dan dikuburkan. Hokum dari pengurusan jenazah adalah fardhu kifayah.

2) Takziyah

Takziyah menurut bahasa adalah menghibur, sedangkan menurut istilah yaitu mengunjungi keluarga yang tertimpa musibah (kematian) untuk menunjukkan rasa ikut berduka cita atas meusibah tersebut, yang mana agar keluarga yang ditinggal dapat mengurangi kesedihan, terhibur, serta mampu bersabar atas musibah yang diterimanya.

12 Beni Kurniawan, Pendidikan Agama Islam untuk Perguruan Tinggi, (Jakarta: Grafindo, 2008), 33-34.

13 Imam Al-Ghazali, Metode Menjemput Maut Perspektif Sufistik, Terj. Ahsin Muhammad, (Bandung: Mizan, 1999), 121.

${ }^{14}$ Priska Eka Putri Widya Yusila, "Peranan Pembinaan Kesejahteraan Keluarga (PKK) dalam Upaya Mempertahankan Sikap Kekeluargaan Masyarakat Kelurahan Manisrejo Kota Madiun”, 5 (Nopember, 2015), 480. 
3) Tahlil

Kata tahlil berasal dari bahasa Arab, yaitu dari kata hallala yang memiliki arti gembira, menjadi sangat, menyucikan dan membaca kalimat La ilaaha illallah. Sedangkan pengertian tahlil yang berlaku di masyarakat adalah rangkaian bacaan yang meliputi pembacaan kalimat tauhid, ayat-ayat al quran, tasbih, shalawat, dan bacaan lain yang semuanya itu dimaksudkan sebagai zikir. Hukum dari tahlil itu sendiri adalah boleh bagi pahala dari bacaan yang dihadiahkan untuk si mayit.

4) Penggalangan Dana

Penggalangan dana atau teyan (bahasa Inggris fundraising) adalah proses pengumpulan kontribusi sukarela dalam bentuk uang atau sumber daya lain dengan meminta sumbangan dari individu, perusahaan, yayasan atau lembaga pemerintah. Penggalangan dana juga merupakan layanan yang digunakan para donatur untuk menyumbangkan hartanya kepada pencari dana, hal ini berarti donatur menjadikan lembaga penggalang dana sebagai perantara yang dalam hukum Islam keperantaraan disebut dengan wasathah, untuk menyalurkan dana sumbangannya kepada pencari dana. ${ }^{15}$

5) Sosialisasi

Sosialisasi menurut Charles $\mathrm{R}$ Wright yang dikutip oleh Sutaryo adalah "proses ketika individu mendapatkan kebudayaan kelompoknya dan menginternalisasikan sampai tingkat tertentu norma-norma sosialnya, sehingga membimbing orang tersebut untuk memperhitungkan harapan-harapan orang lain. ${ }^{16}$

\section{Metode Penelitian}

Dalam penelitian ini peneliti menggunakan pendekatan kualitatif, yang bersifat deskriptif. Deskriptif kualitatif mempelajari permasalahan secara sistematis dan akurat mengenai fakta dan sifat obyek tertentu. Penelitian deskriptif bertujuan untuk memaparkan, menggambarkan dan memetakan fakta-fakta berdasarkan cara pandang atau kerangka berfikir tertentu.

15Dina Mahdania,"Penetapan Biaya Administrasi Platform Di Situs Kitabisa.com Perspektif Hukum Ekonomi Syariah”, (Skripsi: UIN Sunan Gunung Djati Bandung, Bandung, 2018).

16Sutaryo, Dasar-Dasar Sosialisasi, (Jakarta: Rajawali Press, 2004), 156. 


\section{AL-ADABIYAH: Jurnal Pendidikan Agama Islam}

Adapun metode pengumpulan data yang digunakan dalam penelitian ini sebagai berikut:

1. Observasi

Metode observasi adalah suatu metode pengumpulan data dengan cara menyelidiki baik langsung maupun tidak langsung artinya peneliti bisa mengamati dari jauh dan bisa terjun kedalam apa yang diselidiki. ${ }^{17}$ Observasi yang digunakan disini adalah observasi partisipan.

\section{Wawancara (Interview)}

Teknik ini peneliti menggunakan jenis wawancara semi terstruktur. Di mana yang dimaksud wawancara semi terstruktur di sini adalah wawancara yang lebih bebas dari pada wawancara terstruktur.

\section{Dokumenter}

Dokumenter merupakan suatu teknik pengumpulan data dengan cara mengumpulkan dokumen dan data-data yang diperlukan dalam permasalahan penelitian untuk mendapatkan data atau informasi yang berhubungan dengan masalah yang diteliti. Dalam penelitian ini yaitu dokumen yang berkaitan dengan data penelitian internalisasi nilai-nilai ukhuwah Islamiyah melalui kegiatan rukun kematian (RUKEM) Nurud Dholam di desa Glundengan Wuluhan Jember.

Untuk analisis data, peneliti menggunakan teori menurut Matthew B. Miles,

A. M. Huberman adalah sebagai berikut:

\section{Data Collection (Pengumpulan Data)}

Pengumpulan data yaitu pengumpulan data pertama atau mentah yang dikumpulkan dalam suatu penelitian.

\section{Data Condensation (Kondensasi Data)}

Kondensasi data adalah proses menyeleksi, memfokuskan, menyederhanakan, mengabstrakkan dan mentransformasi data yang terdapat pada catatan lapangan, wawancara transkip, dokumentasi dan bahan empiris lainnya. Dengan menggunakan data kondensasi data akan menjadi lebih kuat. ${ }^{18}$ Letak perbedaan antara reduksi data dengan kondensasi data terletak pada cara penyederhanaan data. Reduksi cenderung memilah kemudian

17 Nana Syaodih Sukmadinata, Metode Penelitian Pendidikan..., 220.

18 Miles dan Huberman, Qualitative Data Analysis "A Methods Sourcebook Edition 3" (India: SAGE Publication, 2014), 30. 
memilih, sedangkan kondensasi menyesuaikan seluruh data yang dijaring tanpa harus memilah (mengurangi) data. Data Display (Penyajian Data)

Setelah data dikondensasi, langkah selanjutnya adalah menyajikan data.Penyajian data dalam penelitian kualitatif dilakukan dalam bentuk uraian singkat, bagan atau dengan teks yang bersifat naratif. Dengan menyajikan data, maka akan mempermudah untuk memahami apa yang terjadi dan melakukan sesuatu, menganalisis lebih lanjut atau mengambil tindakan berdasarkan pemahaman itu. ${ }^{19}$

3. Drawing and Verifying Conclusion (Menggambarkan dan Memverifikasi Kesimpulan atau Penarikan Kesimpulan)

Penarikan Kesimpulan yaitu sebuah kegiatan analisis yang penting untuk menarik kesimpulan dan verifikasi. Awal mula pengumpulan data dilakukan oleh seorang penganalisis kualittaif dimulai dari mencari arti benda-benda, mencatat keteraturan penjelasan, alur sebab akibat dan proposisi. Kesimpulan tidak akan muncul sampai pengumpulan data selesai, tergantung pada banyaknya kumpulan dari catatan yang dilakukan di lapangan, pengkodeannya, penyimpanannya dan metode pencarian ulang serta kecakapan peneliti. ${ }^{20}$

\section{Hasil dan Diskusi}

\section{Internalisasi nilai-nilai Ukhuwah Islamiyah melalui kegiatan Rukun Kematian (RUKEM) Nurud Dholam di Desa Glundengan Wuluhan.}

Dalam proses internalisasi ada tiga tahap yang mewakili proses atau tahap terjadinya internalisasi yaitu tahap transformasi nilai yaitu Pada tahap ini hanya terjadi komunikasi verbal, tahap transaksi nilai yaitu suatu tahap pendidikan nilai dengan jalan melakukan komunikasi dua arah, atau interaksi timbal balik dan tahap transinternalisasi yaitu Pada tahap ini bukan hanya dilakukan dengan komunikasi verbal tapi juga sikap mental dan kepribadian yang berperan secara aktif. 21

19 Miles dan Huberman, Qualitative Data Analysis "A Methods Sourcebook Edition 3" (India: SAGE Publication, 2014), 30-31.

${ }^{20}$ Miles dan Huberman, Qualitative Data Analysis "A Methods Sourcebook Edition 3" (India: SAGE Publication, 2014), 31-32.

${ }^{21}$ Muhamimin, Strategi Belajar Mengajar, (Surabaya: Citra Meida, 2006), 153. 


\section{AL-ADABIYAH: Jurnal Pendidikan Agama Islam}

Rukun Kematian merupakan salah satu lembaga non formal yang betujuan untuk meningkatkan skill dan pengetahuan masyarakat sehingga mendapatkan manfaat agar terjalinnya Ukhuwah Islamiyah. Nilai-nilai Ukhuwah Islamiyah yang dapat diinternalisasikan adalah Ukhuwah Ubudiyah, Insaniyah, Wathaniyah Wa Nasab dan Ukhuwah Fi Din al Islam. Sama halnya dengan Trilogi Ukhuwah menurut KH. Ahmad Siddiq yaitu Ukhuwah Islmiyah (Ukhuwah Ubudiyah dan Ukhuwah Fi din al Islam), Ukhuwah Wathaniyah (Wathaniyah wa Nasab), dan Ukhuwah Basyariyah (Ukhuwah Insaniyah). ${ }^{22}$

Pada tahap internalisasi transformasi nilai Ukhuwah Islamiyah melalui kegiatan Rukun Kematian Nurud Dholam yang dilakukan melalui beberapa nilai Ukhuwah menurut KH. Ahmad Siddiq seperti Ukhuwah Islamiyah yaitu persaudaraan yang tumbuh dan berkembang karena persamaan keamanan atau keagamaan, baik ditingkat Nasional maupun Internasional, sebagai modal untuk melakukan pergaulan sosial dengan sesama muslim. Ukhuwah Islamiyah termasuk Ukhuwah Ubudiyah dan Ukhuwah Fi din al Islam. Ukhuwah Wathaniyah yaitu ukhuwah yang tumbuh dan berkembang atas dasar kebangsaan. Sebagai modal untuk melakukan pergaulan sosial dan dialog dengan berbagai komponen bangsa Indonesia (Ukhuwah Wathaniyah Wa Nasab termasuk Ukhuwah Wathaniyah). Ukhuwah Basyariyah yaitu ukhuwah yang tumbuh dan berkembang atas dasar kemanusiaan. (Ukhuwah Basyariyah termasuk Ukhuwah Insaniyah).

Dimana pada tahap internalisasi transaksi nilai penanaman tersebut dilakukan melalui program kegiatan yang telah disepakati bersama seperti program kegiatan bulanan dan tahunan.

Pada tahap internalisasi transinternalisasi yang terjadi dilapangan menunjukkan bahwa nilai-nilai Ukhuwah Islamiyah dalam masyarakat sudah tertanam dengan baik, akan tetapi pada nilai Ukhuwah Ubudiyah masih banyak masyarakat yang belum sadar tentang hal tersebut, seperti dalam menshalatkan jenazah tidak semua mengikuti. Maka nilai Ukhuwah Ubudiyah harus lebih di tanamkan oleh RUKEM.

Ukhuwah Ubudiyah adalah saudara seluruh makhluk hidup yang samasama ciptaan Allah. Dari perspektif sama-sama ciptaan Alloh tersebut yang melatarbelakangi tali persaudaraan terjalin. Akan tetapi kesadaran masyarakat

22 Rudy Al Hana, "Pemikiran KH. Achmad Siddiq Tentang Ukhuwah Islamiyah, Wathaniyah, Basyariyah”, dalam Study Islam, vol IV, Agustus, 2004), 2. 


\section{AL-ADABIYAH: Jurnal Pendidikan Agama Islam}

kurang, hal tersebut dapat disebabkan karna kurangnya pemahaman tentang perspektif sama-sama ciptaan Allah. ${ }^{23}$

\section{Bentuk-bentuk kegiatan Rukun Kematian (RUKEM) Nurud Dholam di Desa Glundengan Wuluhan}

Menurut Kamus Besar Bahasa Indonesia (KKBI) kegiatan merupakan aktivitas, usaha, pekerjaan kekuatan dan ketangkasan serta kegairahan. Dalam suatu organisasi tidak lepas dari suatu kegiatan yang terdiri dari program-program kegiatan, begitu pula organisasi Rukun Kematian. Kegiatan RUKEM yang paling utama adalah mengurus jenazah, membantu mempersiapkan kebutuhan jenazah dan tahlilan.

Berdasarkan penelitian yang telah dilakukan menunjukkaan bahwa, salah satu bentuk kegiatan yang terdapat di Rukun Kematian Nurud Dholam adalah merawat jenazah seperti memandikan, mengkafani, mensholati jenazah, dan menguburkan jenazah serta mendoakan jenazah melalui doa bersama yaitu tahlilan. Menurut Mufid dalam bukunya dengan judul Panduan Lengkap Mengurus Jenazah yang membahas mengenai pokok-pokok pengurusan jenazah terdapat lima tahap yaitu memandikan jenazah, mengkafani jenazah, menyalatkan jenazah dan mengkuburkan jenazah. Kecuali bagi jenazah yang mati syahid, cukup dishalatkan dan dikuburkan. ${ }^{24}$ Berdasarkan uraian diatas menunjukkan bahwa, kegiatan RUKEM Nurud Dholam dalam merawat jenazah sudah sesuai dengan ketentuan syari'at islam.

Selain itu, kegiatan RUKEM Nurud Dholam adalah membersihkan makam, sosialisasi, dan penggalian dana yang dilakukan satu bulan sekali terhadap masyarakat setempat, serta pemeliharaan asset RUKEM Nurud Dholam yang berbentuk pohon sengon sejumlah 700 pohon. Hasil dari pengelolaan asset tersebut direncanakan untuk membeli mobil ambulan yang digunakan untuk menyediakan transportasi bagi warga yang sedang sakit dan membutuhkan pertolongan secara cepat (intens). Selanjutnya, dari seluruh kegiatan yang telah dilakukan oleh RUKEM Nurud Dholam akan didokumentasikan dengan bentuk laporan setiap tahunnya. Laporan tersebut digunakan sebagai bahan evaluasi RUKEM Nurud Dholam melalui musyawarah bersama masyarakat setempat.

23 Quraish Shihab, Wawasan al-Quran, 496 34-74.

24 Ahmad Muf'id, Panduan Lengkap Mengurus Jenzah, (Yogyakarta: MUEEZA, 2019), 


\section{AL-ADABIYAH: Jurnal Pendidikan Agama Islam}

Menurut Charles $\mathrm{R}$ Wright yang dikutip oleh Sutaryo, menyatakan bahwa sosialisasi merupakan proses ketika individu mendapatkan kebudayaan kelompoknya dan menginternalisasikan sampai tingkat tertentu norma-norma sosialnya, sehingga membimbing orang tersebut untuk memperhitungkan harapan-harapan orang lain. ${ }^{25}$ Berdasarkan uraian diatas dapat diketahui bahwa, kegiatan sosialisasi yang dilakukan oleh RUKEM Nurud Dholam dapat berdampak langsung terhadap internalisasi sosial pada masyarakat setempat.

Apresiasi masyarakat Glundengan terhadap organisasi RUKEM Nurud Dholam yaitu sangat setuju, semangat, kompak, guyub terhadap kegiatan RUKEM Nurud Dholam, dan bukan hanya masyarakat pemerintah desa juga bergabung dalam organisasi RUKEM Nurud Dholam ini.

\section{Faktor pendukung dan penghambat kegiatan Rukun Kematian (RUKEM) Nurud Dholam di Desa Glundengan Wuluhan}

Berdasarkan hasil penelitian yang telah peneliti temukan di lapangan. Faktor pendukung kegiatan RUKEM Nurud Dholam di Desa Glundengan Wuluhan adalah adanya dorongan baik dari pemerintah desa maupun masyarakat, adanya kerukunan dan keamanan antar masyarakat, dan sangat diberlakukannya kegiatan RUKEM Nurud Dholam bagi masyarakat dalam membantu proses perawatan jenazah dan tahlilan yang tidak membedakan antara yang kaya dan miskin. Dengan adanya dukungan dari pemerintah desa dan masyarakat sehingga terjalinnya ukhuwah Islamiyah. Sehingga masyarakat dapat secara leluasa melakukan aktivitas sosial terutama dalam hal membantu pengurusan jenazah dan ritual dalam rangka menggapai kebahagiaan hidupSedangkan faktor penghambat kegiatan RUKEM Nurud Dholam di desa Glundengan adalah kurangnya kesadaran masyarakat, dan sangat minimnya pemberdayaan masyarakat. Jika berlangsung terus menerus tanpa adanya tindak lanjut maka akan menyebabkan kegiatan RUKEM Nurud Dholam tidak terlaksana dengan baik. Menurut Nuraini dalam penelitiannya menunjukkan bahwa, terdapat beberapa faktor pendukung yang mempengaruhi masyarakat terhadap nilai-nilai Ukhuwah Islamiyah seperti, motivasi, empati, budaya lingkungan, menciptakan perdamaian,

${ }^{25}$ Sutaryo, Dasar-Dasar Sosialisasi, (Jakarta: Rajawali Press, 2004), 156. 


\section{AL-ADABIYAH: Jurnal Pendidikan Agama Islam}

dan tingkat pendidikan. ${ }^{26} \mathrm{Hal}$ tersebut sangat berpengaruh dengan kegiatan RUKEM Nurud Dholam untuk mewujudkan internalisasi ukhuwah islamiyah pada masyarakat setempat, khususnya masyarakat Glundengan Krajan.

Sedangkan, faktor penghambat dalam kegiatan RUKEM Nurud Dholam di desa Glundengan adalah kurangnya kesadaran masyarakat, dan sangat minimnya pemberdayaan masyarakat. Menurut, DR.Thohir Luth, MA., dalam bukunya dengan judul Tragedi Ukhuwah Telaah Atas Rajutan Ukhuwah Islamiyah Yang Kian Rapu menjelaskan bahwa, terdapat beberapa faktor yang menghambat yang mempengaruhi masyarakat terhadap nilai-nilai Ukhuwah Islamiyah seperti, keras kepala dan tidak mau mendengarkan nasihat, ingkar janji tanpa udzur, berhati dingin, mudah terhasut. ${ }^{27}$ Oleh sebab itu, dibutuhkan cara atau strategi untuk mengatasi kendala tersebut. Berdasarkan hasil penelitian yang telah dilakukan mengenai cara atau strategi yang perlu dilakukan untuk mengatasi hambatan kegiatan RUKEM Nurud Dholam di Desa Glundengan Wuluhan yaitu dengan adanya orang yang disegani di masyarakat Glundengan dan adanya koordinasi antara pemerintah desa, pengurus RUKEM Nurud Dholam dan masyarakat.

Selanjutnya, Dampak positif dari kegiatan RUKEM Nurud Dholam di Desa Glundengan Wuluhan adalah masyarakat terfasilitasi dalam pengurusan jenazah hingga tahlilan seperti memfasilitasi kain kafan, batu nisan, satir, bak air, selang, sabun, sampo, kembang, kapur barus, tong air, meja untuk tempat jenazah, sound system, dan tarop (tenda). Sedangkan dampak negatifnya yaitu panitia merasa keberatan menjalankan tugas pada saat kegiatan RUKEM bahkan ada yang terpaksa dalam menjalankan kegiatan RUKEM sehingga hasilnya kurang maksimal, seperti pada saat sosialisasi keagamaan atau penggalangan dana.

\section{Kesimpulan}

Dalam proses internalisasi melalui tiga tahapan yaitu tahap transformasi nilai, transaksi nilai dan tahap transinternalisasi nilai-nilai Ukhuwah Islamiyah (Ukhuwah Ubudiyah dan Ukhuwah $\mathrm{Fi}$ din al Islam), Ukhuwah Wathaniyah (Ukhuwah Wathaniyah Wa Nasab) dan Ukhuwah Basyariyah (Ukhuwah Insaniyah) melalui kegiatan Rukun Kematian sudah berjalan dengan baik, namun masih ada

26 Nuraini, "Internalisasi Nilai-Nilai Pendidikan Agama Islam Pada Kegiatan Ekstrakulikuler Rohaniah Islam Dalam Membina Karakter Peserta Didik Di SMA Negeri 1 Air Putih Kecamatan Air Putih Kabupaten Batu Bara”, (Desember, 2019), 57.

27 Thohir Luth, Tragedi Ukhuwah Telaah Atas Rajutan Ukhuwah Islamiyah Yang Kian Rapu, (Jakarta: Penamadani, 2003), 81. 


\section{AL-ADABIYAH: Jurnal Pendidikan Agama Islam}

yang kurang sadar dalam hal keagamaan (Ukhuwah Islamiyah pada aspek Ukhuwah Ubudiyah) seperti dalam menshalatkan jenazah tidak semua mengikuti. Maka nilai Ukhuwah Ubudiyah harus lebih di tanamkan oleh RUKEM Nurud Dholam.

Begitu juga organisasi RUKEM Nurud Dholam yang terdiri dari beberapa program yang paling utama diantaranya yaitu mengurus jenazah, membantu mempersiapkan kebutuhan jenazah, perawatan jenazah, pemberangkatan jenazah sampai dengan tahlilan. RUKEM Nurud Dholam juga mempunyai program mengadakan sosialisasi setiap satu tahun dan tiga bulan sekali bersama masyarakat. Dan dalam RUKEM Nurud Dholam juga ada penggalian dana dilakukan setiap bulan kepada masyarakat setempat.

Sesuai dengan teori Nuraini dan Tohir Luth menyatakan bahwa faktor pendukung kegiatan RUKEM Nurud Dholam di Desa Glundengan Wuluhan yaitu adanya dorongan baik dari pemerintah desa setempat maupun masyarakat, dan kerukunan tanpa membedakan antara yang satu dengan yang lain. Sedangkan sesuai dengan teori Hisyam bin Abdul Qodir Uqdah yang menyatakan bahwa faktor penghambat kegiatan RUKEM Nurud Dholam di desa Glundengan adalah kurangnya kesadaran masyarakat, dan sangat minimnya pemberdayaan masyarakat dalam kegiatan RUKEM. Cara mengatasi hambatan kegiatan RUKEM Nurud Dholam di Desa Glundengan Wuluhan yaitu mengadakan sosialisasi dari toko masyarakat setempat yang disegani, adanya kordinasi dengan pemerintahan setempat dan juga pengurus RUKEM.

\section{Referensi}

Adisusilo, Sutarjo. 2012. Pembelajaran Nilai Karakter. Jakarta: PT Rajagrafindo Persada.

Bungin, Burhan. 2011. Metode Penelitian Kuantitatif. Jakarta: Kencana.

Depdikbud.1989. Kamus Besar Bahasa Indonesia. Jakarta: Balai Pustaka.

Dina Mahdania.2018. "Penetapan Biaya Administrasi Platform Di Situs Kitabisa.com Perspektif Hukum Ekonomi Syariah", (Skripsi: UIN Sunan Gunung Djati Bandung.

Ghazali, Imam. 1999. Metode Menjemput Maut Perspektif Sufistik, Terj. Ahsin Muhammad. Bandung: Mizan.

Hasan, Muhammad Tholhah. 2003.Prospek Islam dalam Menghadapi Tantangan Zaman.Jakarta: Lantabora Press. 


\section{AL-ADABIYAH: Jurnal Pendidikan Agama Islam}

Karim, Abdul. 2002. Petunjuk Shalat Jenazah dan Permasalahannya. Jakarta: Amzah.

Kurniawan, Beni. 2008. Pendidikan Agama Islam untuk Perguruan Tinggi. Jakarta: Grafindo.

Mahmud, Ali Abdul Halim. 1998. Fiqh Responsibilitas Tanggung Jawab Muslim dalam Islam. Jakarta: Gema Insani.

Miles dan Huberman. 2014. Qualitative Data Analysis "A Methods Sourcebook Edition 3". India: SAGE Publication.

Moleong, Lexy J. 2010. Metodologi Penelitian Kualitatif. Bandung: Remaja Rosdakarya.

Muhamimin. 2006. Strategi Belajar Mengajar. Surabaya: Citra Meida.

Nadzir, Moh. 2003. Metode Penelitian. Jakarta: Ghalia Indonesia.

Nashir, Haidar.1997. Agama dan Krisis Kemanusiaan Modern. Yogyakarta: Pustaka Pelajar.

Priska Eka Putri Widya Yusila. "Peranan Pembinaan Kesejahteraan Keluarga (PKK) dalam Upaya Mempertahankan Sikap Kekeluargaan Masyarakat Kelurahan Manisrejo Kota Madiun", 5 (Nopember, 2015).

Peraturan Menteri Pendidikan dan Kebudayaan Nomor 81 Tahun 2013 tentang Pendirian Satuan Pendidikan NonFormal.

Peraturan Pemerintah Nomor 17 Tahun 2010 tentang Pengelolaan dan Penyelenggaraan Pendidikan.

Rudy Al Hana. "Pemikiran KH. Achmad Siddiq Tentang Ukhuwah Islamiyah, Wathaniyah, Basyariyah", dalam Study Islam, vol IV, (Agustus, 2004).

Shihab, M. Quraish. 1996. Wawasan Alquran. Bandung: Mizan.

Soekamto, Sarjono. 2000. Kamus Sosiologi. Jakarta: Raja Wali Press.

Sugiono. 2009. Metode Penelitian Pendidikan "Pendekatan Kuantitatif Kualitatif dan $R \& D ”$. Bandung: Alfabeta.

Sugiono. 2010. Metode Penelitian Pendidikan "Pendekatan Kuantitatif Kualitatif dan $R \& D ”$. Bandung: Alfabeta.

Sutaryo. 2004. Dasar-Dasar Sosialisasi. Jakarta: Rajawali Press.

Sekretariat Negara RI, Undang-undang Nomor 20 Tahun 2003 Tentang Sistem Pendidikan Nasional.

Thoha, Chabib. 2006. Kapita Selekta Pendidikan Islam. Yogyakarta: Pustaka Pelajar. 


\section{AL-ADABIYAH: Jurnal Pendidikan Agama Islam}

Tim Penyusun Kamus Pusat Bahasa. 2005. Kamus Besar Bahasa Indonesia.Jakarta: Balai Pustaka.

Rudy Al Hana. "Pemikiran KH. Achmad Siddiq Tentang Ukhuwah Islamiyah, Wathaniyah, Basyariyah”, dalam Study Islam, vol IV, (Agustus, 2004). 